L. D. Larson, Advisory Engineer (Retired)

D. P. Jones, Advisory Engineer

D. G. Rapp, Manager

DE-AC11-93PN38195

RECEIVED

NOV 169998

OSTI

This report was prepared as an account of work sponsored by the United States Government. Nelther the United States, nor the United States Department of Energy, nor any of their employees, nor any of their contractors, subcontractors, of their employees, makes any warranty, express or implied, or assumes any logal liablity or responsibility for the accuracy, completeness or usefulness of any Information, apparatus, product or process disclosed, or represents that its use would not Infringe privately owned rights. 


\section{DISCLAIMER}

This report was prepared as an account of work sponsored by an agency of the United States Government. Neither the United States Government nor any agency thereof, nor any of their employees, makes any warranty, express or implied, or assumes any legal liability or responsibility for the accuracy, completeness, or usefulness of any information, apparatus, product, or process disclosed, or represents that its use would not infringe privately owned rights. Reference herein to any specific commercial product, process, or service by trade name, trademark, manufacturer, or otherwise does not necessarily constitute or imply its endorsement, recommendation, or favoring by the United States Government or any agency thereof. The views and opinions of authors expressed herein do not necessarily state or reflect those of the United States Government or any agency thereof. 


\section{DISCLAIMER}

Portions of this document may be illegible in electronic image products. Images are produced from the best available original document. 


\title{
Tension Bending Ratcheting Tests of 304 Stainless Steel
}

\author{
L.'D. Larson \\ D. P. Jones \\ D. G. Rapp
}

Westinghouse Electric Corporation

West Mifflin, PA 15122-0079

\section{ABSTRACT}

This paper discusses results of an experimental program conducted to investigate the strain ratcheting behavior of 304 stainless steel under various combinations of applied membrane load and displacement controlled cyclic bending strain. Tests were performed on uniaxial specimens at temperatures of $70^{\circ} \mathrm{F}\left(21^{\circ} \mathrm{C}\right)$ and $550^{\circ} \mathrm{F}\left(288^{\circ} \mathrm{C}\right)$. Bending strain, ratchet strain and axial displacement of the specimens were monitored throughout the tests. Membrane stress to monotonic yield stress ratios of $2 / 3,1 / 2$, and $1 / 3$ were tested with pseudo-elastic bending stress to yield stress ratios ranging from 1.4 to 10.7 . Test output was in the form of plots of cumulative axial membrane strain versus cycles up to the point of shakedown, i.e., the point at which no additional progressive strain was observed. Shakedown was demonstrated in the $550^{\circ} \mathrm{F}$ tests but not the room temperature tests. The $550^{\circ} \mathrm{F}$ results are shown in terms of shakedown membrane strain versus equivalent bending stress ratio for each of the tested membrane stress ratios. The cyclic and monotonic stress-strain curves for the test materials are presented to enable the use of various models for predicting the ratcheting and shakedown behavior. The results may be used to develop improved ratcheting and shakedown rules permitting a relaxation of the traditional ratcheting rules in the ASME Boiler and Pressure Vessel

Code.

Nomenclature

$\Delta \varepsilon_{\mathrm{b}}=$ applied bending strain range

$\varepsilon_{S}=$ shakedown strain

$\varepsilon_{R}=$ applied strain range in cyclic stress strain tests

$\varepsilon_{\mathrm{T}}=$ ratchet strain

$\dot{\varepsilon}=$ strain rate, [strain $/ \mathrm{min}$.]

$\Delta S_{R}=$ stabilized stress range

$\mathrm{T}=$ membrane tension

$\mathrm{M}_{\mathrm{e}}=$ bending moment

$\theta_{\mathrm{e}}=$ rotation angle

$\delta_{\mathrm{x}}=$ deflection

$\mathrm{Y}_{\mathrm{c}}, \mathrm{Y}_{\mathrm{x}}=$ shear loads

$\mathrm{L}_{\mathrm{T}}=$ specimen length

$\mathrm{L}_{\mathrm{G}}=$ specimen gage length

$\mathrm{S}_{\mathrm{M}}=$ membrane stress

$S_{B}=$ equivalent elastic bending stress range, $E \Delta \varepsilon_{b}$ $S_{y}=0.2 \%$ offset monotonic yield stress

$\mathrm{E}=$ Young's Modulus 


\section{Introduction}

The ASME Boiler \& Pressure Vessel Code (hereafter, the Code) includes a limit on the primary plus secondary stress intensity range of $3 \mathrm{Sm}$ in conjunction with the primary membrane stress of $S_{M}$. These limits are intended to provide protection against progressive deformation by the ratcheting mode. In addition to protection against ratcheting, these limits assure validity of the fatigue procedure by limiting local strains to values consistent with elastically calculated strains due to elastic shakedown of the surrounding structure. Welded seals, such as omega or canopy, are examples where the $3 \mathrm{Sm}$ limit is not easily met and where special limits are applied per NB3227.7 of the Code which states that the ratchet limits of NB-3228.5(d) of the Code need not apply. Generally, any application of NB-3228.5 of the Code should require an evaluation for ratcheting. The particular failure mode of interest in this case is local ratcheting at a critical cross section of the seal which is subject to high secondary bending stresses induced by the motions imposed upon the seal by the surrounding structure.

A conservative basis for preventing ratcheting is available in the Bree chart (Bree, 1967) for ideal elastic-perfectly plastic material. However, this approach can be quite conservative for materials with significant cyclic hardening such as austenitic steels subject to combined steady state membrane stress and cyclic bending strain. The tension-bending test program described in this paper was designed to produce data for a range of loading parameters in order to qualify an extension of the Bree chart for monotonic ratchet strains of $1 \%$ and greater. The data were developed on Alloy 600 and 304 stainless steel (SS) at room temperature and $550^{\circ} \mathrm{F}\left(288^{\circ} \mathrm{C}\right)$. The cyclic and monotonic properties for the test materials were well characterized to permit prediction of the data by various constitutive models. Results of tests on Alloy 600 were previously reported by
Larson, et al (1995).

\section{Material Stress Strain Properties}

The 304SS material used in the tension bending tests had monotonic $0.2 \%$ offset yield stresses near Code values. The actual values were 32.5 and $\mathbf{1 8 . 2}$ ksi (224 and $126 \mathrm{MPa}$ ) at room temperature and $550^{\circ} \mathrm{F}\left(288^{\circ} \mathrm{C}\right)$, respectively versus values listed in Code material property tables of 30 and $18.75 \mathrm{ksi}$ (207 and $129 \mathrm{MPa}$ ). The strain rate in these basic tests was $0.05 / \mathrm{min}$. An additional test at a strain rate of $0.005 / \mathrm{min}$ was performed to provide information on the strain rate effect. The monotonic stress strain curves are presented in Figure 1. Young's modulus for this material was assumed to be $28.3 \times 10^{6} \mathrm{psi}\left(195 \times 10^{3} \mathrm{MPa}\right)$ at room temperature and $25.8 \times 10^{6} \mathrm{psi}\left(178 \times 10^{3}\right.$ $\mathrm{MPa})$ at $550^{\circ} \mathrm{F}\left(288^{\circ} \mathrm{C}\right)$. Ramberg-Osgood type stress strain curves shown in the figure were obtained using the NLFIT (Marquardt, 1963) nonlinear curve fitting program.

Cyclic stress strain curves were also developed at both room temperature and $550^{\circ} \mathrm{F}\left(288^{\circ} \mathrm{C}\right)$. An hourglass specimen with diametral strain control was utilized in these tests. Cyclic strain data were obtained from both multiple specimen tests and single specimen tests in which the cyclic strain range was increased after stabilization was achieved at a given strain range. The room temperature results are summarized in Table 1 and the $550^{\circ} \mathrm{F}\left(288^{\circ} \mathrm{C}\right)$ data is given in Table 2 .

As reflected in the last column of Table 1, the room temperature results show that stress ranges developed by stepping down from higher strain ranges are somewhat higher than the corresponding stress ranges in the step up phase. This behavior is particularly evident by comparing results for specimen $\mathrm{SCl}$ with results for specimens $\mathrm{SC} 2, \mathrm{SC} 3, \mathrm{SC} 16$ and $\mathrm{SC} 5$ suggesting that strain amplitude and order effects are important. The $550^{\circ} \mathrm{F}$ data in Table 2 show little effect of prior cycling during the step up phase but 
do show an effect during the step down phase. Table 3 summarizes results of multiple specimen tests at $550^{\circ} \mathrm{F}$. The results agree very well with the average results for the multiple step tests in Table 2. As shown in the last column of Table 3 , decreasing the strain rate increased the cyclic hardening response of the material. The cyclic stress-strain curves shown in Figure 2 were obtained by fitting data from the step up phase to the Ramberg-Osgood type equation using NLFIT (Marquardt, 1963). The observation that cyclic history effects is important particularly of room temperature for 304 stainless steel is consistent with the findings of Jaske (1973), Conway and Stentz (1988), and Conway, et al (1975).

\section{Tension Bending Test Apparatus}

The basic test concept used to produce the combined tension and bending loading is illustrated schematically in Figure 3. The specimen is loaded axially in tension by a dead weight load $\mathrm{T}$ which develops a primary membrane stress, $\sigma_{\mathrm{M}}$. The ends of the specimen are then rotated cyclically $\left( \pm \theta_{\mathrm{e}}\right)$ to produce the desired bending strain range (secondary stress range), $\Delta \varepsilon_{b}$. One end of the specimen is free to translate axially so ratcheting (progressive growth) can take place. The loading concept is intended to produce essentially a combination of pure bending and axial force in the gage length, $\mathrm{L}_{\mathrm{G}}$. The pure bending condition can be approached but not fully attained because the axial force causes a contribution to the bending moment when the specimen is bent out of its plane. The test specimen, Figure 4, was designed to minimize the strain variation along the gage length by keeping it as short as possible and varying the thickness. Figure 5 is a photograph of the loading assembly and apparatus.

\section{Instrumentation}

Six uniaxial strain gages were located on the specimen; two on opposite sides of each shoulder to measure the elastic bending strains and two on opposite sides of the gage mid-length to measure the membrane strain. For the measurement of membrane strain in the gage section, high elongation type gages were used in the room temperature tests and temperature resistant gages were used in the $550^{\circ} \mathrm{F}$ tests.

Load cells were located on both the horizontal driving ram and vertical shaft of the tension bending loading assembly. The output of the vertical load cell served as a check on the consistency of axial loading applied during cycling. The cyclic loading required to deflect the specimen during bending can be determined from the output of the horizontal load cell and was useful in calculating the strains in the elastic region of the specimens should the strain gages malfunction. A special elongation gage was used for back-up measurement of the axial growth of the specimen. Elongation was converted to strain using an effective gage length of 0.825 inches. The final cumulative strains were also checked by determining the increase in the gage length from before and after measurements of scribe lines.

Data collection during a test was accomplished through an 8-channel Beckman Recorder so that output from the strain gages and load cells versus cycles could be continuously recorded. A parallel circuit was used to record data at peak values by momentarily stopping the specimen at its maximum right and left displacements.

\section{Results of Room Temperature Tests}

The results of the room temperature tests are summarized in Figures 6 and 7. Figure 6 shows cumulative strain versus cycles for an applied membrane stress of $2 / 3$ Sy and four different bending strain ranges shown in the figures as $S_{B} / S_{y}$ where $S_{B}=E \Delta \varepsilon_{b}$. As seen in Figure 6 and 7 , shakedown was obtained for specimen SB1 only. Since it was thought that shakedown should occur for a strain hardening material, an investigation 
into possible test problems was performed and an elongation gage was added as a check on the strain gage readings.

Figure 7 shows results for an applied membrane stress of $1 / 2 S_{y}$. Again, shakedown was not obtained and the strain estimates based on elongation of the gage length verified the strain gage measurements. High elongation stain gages were chosen for the room temperature tests because it was felt they would survive the expected high cumulative strains. However, testing of several specimens in bending only (no membrane load) demonstrated that the gage drift is small on a per cycle basis but can introduce significant cumulative error in the monotonic strain when the cycles exceed about 1000. The dashed curves in Figures 6 and 7 show the estimated corrections based on elimination of the gage drift. In Figure 6, it appears that gage error could account for the lack of shakedown. However, this is not the case in Figure 7. The load instrumentation indicated that the bending moment in the gage section stabilized in less than 1000 cycles.

It is apparent from Figures 6 and 7 that many cycles may be required to reach complete shakedown at room temperature. This prolonged shakedown period is considered due to time and history dependent cyclic strain hardening affects that are more pronounced at room temperature than at elevated temperature.

\section{Results of $550^{\circ} \mathrm{F}\left(288^{\circ} \mathrm{C}\right)$ Tests}

The initial test procedure was to test a single specimen at a given membrane load ratio, $\mathrm{S}_{\mathrm{M}} / \mathrm{S}_{\mathrm{y}}$ and equivalent bending stress ratio, $S_{\mathrm{B}} / \mathrm{S}_{\mathrm{y}}$. Results of these tests are shown in Figures 8, 9, and 10.

Cumulative strain versus cycles for the $550^{\circ} \mathrm{F}$ tests at a membrane load of $2 / 3 \mathrm{~S}_{\mathrm{y}}$ are shown in Figure 8. The data for specimens SB10 and SB13 show that shakedown definitely occurred. The strain gage data for specimens SB8 and SB11 show that shakedown was nearly achieved. Strains were measured with both high temperature strain gages and an elongation gage and show agreement over the survival time of the gages. Also, final strains were estimated by pre and post scribe line measurements and these agree with the final values measured by the elongation gages. Because shakedown was demonstrated in these tests, the test procedure was revised to take advantage of this and make more economical use of the specimens.

The procedure used in the remaining $550^{\circ} \mathrm{F}$ tests was designed to maximize the data obtained from a single specimen. The multiple step cyclic stress strain data in Tables 1 and 2 show that the effect of prior cycling on the cyclic properties is small if the cyclic strain range is increased after stabilization for a given strain range. Therefore, the applied bending strain range was set relatively low in the first test block and the specimen was cycled until the membrane strain ceased to increase with further cycling. A second test block with a higher bending strain range was then initiated. By repeating this process, a single specimen could be used to generate shakedown data for several different bending strain ranges for a particular value of membrane stress. Figures 9 and 10 show examples of this. In Figure 9, cumulative strain at shakedown for a $S_{M} / S_{y}$ ratio of $1 / 2$ was determined for six different equivalent elastic bending strain range ratios. In Figure 10, shakedown was demonstrated for five different $S_{B} / S_{y}$ ratios with $S_{M} / S_{y}=1 / 3$.

Hold times of up to an hour were incorporated at various times in these tests and showed negligible effect on cumulative strain.

\section{Interpretation of Results}

The results of these tests demonstrate that shakedown can be difficult to achieve in 304 stainless steel at room temperature probably due to 
cyclic strain rate effects that are more pronounced at room temperature than at elevated temperature. A contributing factor to the prolonged ratcheting at room temperature is the relatively low strain hardening of the monotonic stress strain curve and the fact that decreasing strain rates lead to lower stress magnitudes for a given strain. This is seen in Figure 1 by comparing the $0.05 / \mathrm{min}$. strain rate results with the $0.005 / \mathrm{min}$. curve. Pronounced strain rate effects are not observed at $550^{\circ} \mathrm{F}\left(288^{\circ} \mathrm{C}\right)$ as seen in Figure 2. The center core of the specimen essentially carries the membrane load and this section is controlled by the monotonic strain rate effects rather than cyclic stress-strain effects since only the outer fibers of the specimen are cycled by bending. Thus, a prolonged shakedown period is experienced at room temperature as the monotonic strain rate decreases the monotonic stress-strain curve as shakedown is approached

The results for the elevated temperature are of more practical interest since many pressure vessel and piping applications involve temperatures greater than room temperature. Also, the test matrix for the elevated temperature tests include tests with membrane-to-yield stress ratio down to 1/3 which is typical of ASME B\&PV code applications. Therefore, lack of shakedown at room temperature is not considered critical to the application of results. The results of the $550^{\circ} \mathrm{F}$ tests are summarized in Table 4 and plotted in Figure 11.

For each value of $\left[\mathrm{S}_{\mathrm{M}} / \mathrm{S}_{\mathrm{y}}\right]$, the $550^{\circ} \mathrm{F}\left(288^{\circ} \mathrm{C}\right)$ data were fit to an equation of the form

$$
\varepsilon_{S}=B_{1}\left[S_{B} / S_{y}\right]^{2}
$$

using the NLFIT (Marquardt, 1963) program. Using the data in Table 4, the following results were obtained

$$
\begin{aligned}
& \varepsilon_{S}=0.02524\left[S_{B} / S_{y}\right]^{2} \text { for }\left[S_{m} / S_{y}\right]=1 / 3 \\
& \varepsilon_{S}=0.07195\left[S_{B} / S_{y}\right]^{2} \text { for }\left[S_{m} / S_{y}\right]=1 / 2
\end{aligned}
$$

$$
\varepsilon_{S}=0.1162\left[S_{B} / S_{y}\right]^{2} \text { for }\left[S_{m} / S_{y}\right]=2 / 3
$$

These equations are compared to the data in Figure 11.

Although shakedown was not demonstrated in the room temperature tests, the ratchet strain can be obtained from Figures 6 and 7 for a particular number of cycles. For example, the ratchet strains for 200 cycles given in Table 5 were obtained from Figure 6 and 7 for various values of $S_{B} / S_{y}$ and $\mathrm{S}_{\mathbf{M}} / \mathrm{S}_{\mathbf{y}}$

The thermal stress ratchet limit in the ASME B\&PV Code is given by Paragraph NB-3222.5 which provides two cases. Case 1 is for linear variation of the thermal stress through the wall and Case 2 is for parabolic constantly increasing variation of temperature through the wall. The results provided herein are cast in terms of the ASME Code procedure and shown graphically in Figure 12. The present results are analogous with Case 1 where the bending stress is equivalent to the thermal stress. The $0 \%$ strain curve in Figure 12 represents the Code limit boundary on ratchet strain given by the equations

$$
\begin{aligned}
& S_{B} / S_{y}=1 /\left[S_{M} / S_{y}\right] \text { for }\left[S_{M} / S_{y}\right] \leq 0.5 \\
& S_{B} / S_{y}=4\left[1-S_{M} / S_{y}\right] \text { for } 0.5<S_{M} / S_{y} \leq 1.0
\end{aligned}
$$

The curves for strains of $1 \%, 2 \%$ and $3 \%$ were constructed from the best fit lines in Figure 10 and give the locus of actual shakedown for the material tested in this program. These curves were obtained using NLFIT to fit equations of the form $\left[\mathrm{S}_{\mathrm{B}} / \mathrm{S}_{\mathrm{y}}\right]=$ $\mathrm{B} /\left[\mathrm{S}_{\mathrm{M}} / \mathrm{S}_{\mathrm{y}}\right]$ using $\left[\mathrm{S}_{\mathrm{B}} / \mathrm{S}_{\mathrm{y}}\right]$ values from Equations (2), (3), and (4) for $1 \%, 2 \%$ and $3 \%$ shakedown strain at $\left[S_{M} / S_{y}\right]=1 / 3,1 / 2$, and $2 / 3$. The equations for $1 \%, 2 \%$, and $3 \%$ ratchet strain are

$$
\begin{aligned}
& 1 \% \text { strain; } S_{B} / S_{y}=2.014 /\left[S_{M} / S_{y}\right] \\
& 2 \% \text { strain; } S_{B} / S_{y}=2.849 /\left[S_{M} / S_{y}\right] \\
& 3 \% \text { strain; } S_{B} / S_{y}=3.489 /\left[S_{M} / S_{y}\right]
\end{aligned}
$$


These equations are plotted with supporting data in Figure 12. The curves represent boundaries between regimes of bounded ratcheting. For a particular ratchet strain, shakedown is obtained after ratcheting up to the ratchet strain. The regime to the left of a ratcheting strain curve represents the regime of stabilized shakedown for that particular ratchet strain while the regime to the right represents continuing ratcheting to some higher value. The regime to the left of the zero percent strain line represents the region of elastic shakedown with no accumulated ratchet strain while the region to the right represents safe ratchet strain up to a particular value. For example, the $1 \%$ curve represents the locus of bending stress ratio and membrane stress ratio which results in $1 \%$ cumulative membrane ratchet strain. This suggests the possibility of relaxing Code rules when a permanent membrane strain of $1 \%$ can be tolerated in the component.

\section{Conclusion}

The shakedown behavior of 304 SS at room temperature and $550^{\circ} \mathrm{F}\left(288^{\circ} \mathrm{C}\right)$ has been investigated. A significant database on shakedown has been generated and is supported by detailed characterization of the monotonic and cyclic properties of the material. The shakedown data demonstrates that the ASME Code ratchet rules are conservative and suggests that the rules could be relaxed at low values of $S_{M} / S_{y}$ when some small amount of membrane straining is not objectionable.

\section{Acknowledgments}

The authors wish to acknowledge J. E. Mutter and D. T. Hunter for their efforts on test stand and instrumentation development and on the preliminary phase of testing. The authors also acknowledge the efforts of B. S. Holly who prepared the figures.

\section{References}

J. Bree, 1967, "Elastic-Plastic Behavior of Thin Tubes Subjected to Internal Pressure and Intermittent High-Heat Fluxes with Applications to Fast Nuclear-Reactor Fuel Elements", Journal of Strain Analysis, Vol. 2, No.3, pp. 226-238.

J. B. Conway, J. H. Stentz, and J. T. Berling, 1975, Fatigue Tensile and Relaxation Behavior of Stainless Steels.ain Analysis, Vol. 2, No. 3, pp. 226-238.

J. B. Conway and R. H. Stentz, 1988, "Cyclic Hardening and Softening Behavior of Wrought and Cast Carbon Steel and 304 Stainless Steel" Fatigue Initiation. Propagation and Analysis for Code Construction, MPC Vol 29, American Society of Mechanical Engineers, pp. 91-113.

C. E. Jaske, H. Mindlin, and J. S. Perrin, 1973, "Cyclic Stress-Strain Behavior of Two Alloys at High Temperature," Cyclic Stress-Strain Behavior Analysis, Experimentation, and Failure Prediction, ASTM STP 519, American Society for Testing and Materials, pp. 13-27.

L. D. Larson, D. P. Jones and R. G. Hoppe, 1995, "Tension Bending Ratcheting Tests of NiCrFe Alloy 600," in Fatigue and Crack Growth: Environmental Effects Modeling Studies, and Design Considerations, PVP-Vol. 306, ASME, pp. 155-167.

D. W. Marquardt, 1963, "An Algorithm for LeastSquares Estimation of Non-Linear Parameters," Journal of the Society of Industrial and Applied Mechanics, Vol. 11, No. 2, pp. 431-441. 
TABLE 1

CYCLIC STRESS STRAIN RESULTS ROOM TEMPERATURE

\begin{tabular}{|c|c|c|c|c|c|c|}
\hline$\theta_{R}$ & $\begin{array}{l}S_{R}(S C 1) \\
k s i(M P a)\end{array}$ & $\begin{array}{l}S_{R}(S C 2) \\
k s i(M P a)\end{array}$ & $\begin{array}{l}S_{R}(S C 3) \\
k s i(M P a)\end{array}$ & $\begin{array}{l}S_{R}(S C 16) \\
k s i(M P a)\end{array}$ & $\begin{array}{l}S_{R}(S C 5) \\
k s i(M P a)\end{array}$ & $\begin{array}{c}S_{R}(A V E) \\
k s i(M P a)\end{array}$ \\
\hline 0.002 & $53.5(369)$ & - & - & - & $53.5(369)$ \\
\hline 0.005 & $75.4(520)$ & $64.7(446)$ & - & - & - & $70.1(484)$ \\
\hline 0.010 & $87.7(605)$ & $80.0(552)$ & $81.5(562)$ & $83.1(573)$ \\
\hline 0.015 & $96.1(663)$ & $88.3(609)$ & $88.8(613)$ & $92.5(638)$ & & $91.4(630)$ \\
\hline 0.020 & $105.2(726)$ & $94.4(651)$ & $94.9(655)$ & $99.9(689)$ & $103.6(715)$ & $99.6(687)$ \\
\hline 0.025 & $123.4(851)$ & $102.7(708)$ & $99.9(689)$ & $108.8(751)$ & $124.2(857)$ & $111.8(771)$ \\
\hline 0.030 & $161.4(1113)$ & $114.4(789)$ & $105.1(725)$ & $139.6(963)$ & $140.6(970)$ & $132.2(912)$ \\
\hline 0.025 & - & - & $102.0(704)$ & $132.5(914)$ & $134.5(928)$ & $123.0(848)$ \\
\hline 0.020 & - & - & $93.9(648)$ & $124.3(857)$ & $125.2(864)$ & $115.9(799)$ \\
\hline 0.015 & - & - & $112.9(779)$ & $116(800)$ & $114.5(790)$ \\
\hline 0.010 & & - & - & $106.7(736)$ & $106.7(736)$ \\
\hline
\end{tabular}

TABLE 2

CYCLIC STRESS STRAIN RESULTS, $550^{\circ} F, e_{R}=0.03 / \mathrm{min}$

\begin{tabular}{|c|c|c|c|c|c|c|}
\hline$e_{R}$ & $\begin{array}{c}S_{R}(S C 15) \\
k s i(M P a)\end{array}$ & $\begin{array}{c}S_{R}(S C 7) \\
k s i(M P a)\end{array}$ & $\begin{array}{c}S_{R}(S C 8) \\
k s i(M P a)\end{array}$ & $\begin{array}{l}S_{A}(S C 9) \\
k s i(M P a)\end{array}$ & $\begin{array}{c}S_{R}\left(S_{12}\right) \\
\text { ksi(MPa) }\end{array}$ & $\begin{array}{l}S_{R}(A V E) \\
k s i(M P a)\end{array}$ \\
\hline 0.002 & $35.4(244)$ & - & - & - & - & $35.4(244)$ \\
\hline 0.005 & $46.7(322)$ & $46.7(322)$ & - & - & - & $46.7(322)$ \\
\hline 0.010 & $70.2(484)$ & $68.8(475)$ & $70.8(489)$ & - & - & $69.9(482)$ \\
\hline 0.015 & $87.3(602)$ & $85.3(589)$ & $86.3(595)$ & $90.3(623)$ & - & $87.3(602)$ \\
\hline 0.020 & $100.7(695)$ & $98.5(680)$ & $101.7(702)$ & $101.6(701)$ & $104.8(723)$ & $101.5(700)$ \\
\hline 0.025 & $113.0(780)$ & $113.9(786)$ & $114.0(787)$ & $114.0(787)$ & $114.0(787)$ & $113.8(785)$ \\
\hline 0.030 & $123.4(851)$ & $123.3(85)$ & $123.3(851)$ & $123.2(850)$ & $123.2(850)$ & $123.3(851)$ \\
\hline 0.025 & - & $114.0(787)$ & $116.0(800)$ & $115.0(794)$ & $117.0(807)$ & $115.5(797)$ \\
\hline 0.020 & - & - & $98.6(680)$ & $106.8(737)$ & $105.7(729)$ & $103.7(716)$ \\
\hline 0.015 & - & - & - & $102.7(709)$ & $94.5(652)$ & $98.6(680)$ \\
\hline 0.010 & - & - & - & - & $76.0(524)$ & $76.0\{524\}$ \\
\hline
\end{tabular}

Notes: $\quad e_{\mathrm{R}} \quad=$ Applied strain range

$S_{A}(S C 1)=$ Stabilized Stress Range (Specimen Identity) 
TABLE 3

MULTIPLE SPECIMEN TESTS AT 550 $\mathrm{F}$

\begin{tabular}{|c|c|c|c|}
\hline Specimen & $e_{p}$ & $\begin{array}{c}\mathrm{S}_{\mathbf{R}}(\dot{\varepsilon}=0.03 / \mathrm{min}) \\
\mathrm{ksi}(\mathrm{MPa})\end{array}$ & $\begin{array}{c}S_{\mathbf{R}}(\dot{\varepsilon}=0.0003 / \mathrm{min}) \\
\mathrm{ksi}(\mathrm{MPa})\end{array}$ \\
\hline SC10 & 0.005 & $45.20(312)$ & $74.97(517)$ \\
\hline SC11 & 0.015 & $87.30(602)$ & $98.80(682)$ \\
\hline $\mathrm{SC} 13$ & 0.025 & $115.90(800)$ & $122.23(843)$ \\
\hline
\end{tabular}

TABLE 4 SUMMARY OF $550^{\circ} \mathrm{F}\left(288^{\circ} \mathrm{C}\right)$ TEST RESULTS

\begin{tabular}{|c|c|c|c|c|}
\hline Specimen & Test Block & $\mathbf{S}_{\mathbf{M}} / \mathbf{S}_{\mathbf{Y}}$ & $\mathbf{S}_{\mathrm{B}} / \mathbf{S}_{\mathbf{Y}}$ & $\varepsilon_{r}(1)$ \\
\hline SB 10 & 1 & $2 / 3$ & 2.85 & 0.012 \\
\hline SB13 & 1 & $2 / 3$ & 2.17 & 0.007 \\
\hline SBII & 1 & $2 / 3$ & 5.27 & 0.029 \\
\hline SB8 & 1 & $2 / 3$ & 4.85 & 0.030 \\
\hline SB6 & 1 & $1 / 2$ & 2.57 & 0.004 \\
\hline SB6 & 2 & $1 / 2$ & 3.28 & 0.010 \\
\hline SB6 & 3 & $1 / 2$ & 4.13 & 0.014 \\
\hline SB6 & 4 & $1 / 2$ & 5.84 & 0.026 \\
\hline SB6 & 5 & $1 / 2$ & 6.41 & 0.029 \\
\hline SB6 & 6 & $1 / 2$ & 7.84 & 0.043 \\
\hline SB7 & 1 & $1 / 3$ & 2.57 & 0.001 \\
\hline SB7 & 2 & $1 / 3$ & 4.42 & 0.004 \\
\hline SB7 & 3 & $1 / 3$ & 7.13 & 0.013 \\
\hline SB7 & 4 & $1 / 3$ & 8.69 & 0.019 \\
\hline SB7 & 5 & $1 / 3$ & 10.69 & 0.029 \\
\hline
\end{tabular}

(I) ratchet strain
TABLE 5 SUMMARY OF ROOM TEMPERATURE RESULTS

\begin{tabular}{|c|c|c|c|c|}
\hline Specimen & $\begin{array}{c}\text { Test } \\
\text { Block }\end{array}$ & $S_{W} / S_{y}$ & $S_{8} / S_{y}$ & $\theta_{200}(1)$ \\
\hline SB1 & 1 & $2 / 3$ & 7.2 & 0.071 \\
\hline SB2 & 1 & $2 / 3$ & 1.77 & 0.009 \\
\hline SB2 & 2 & $2 / 3$ & 2.52 & 0.025 \\
\hline SB3 & 1 & $2 / 3$ & 4.2 & 0.040 \\
\hline SB4 & 1 & $1 / 2$ & 2.78 & 0.014 \\
\hline SB5 & 1 & $1 / 2$ & 1.43 & 0.002 \\
\hline SB14 & 1 & & 4.96 & 0.036 \\
\hline
\end{tabular}

Note: (1) $\varepsilon_{200}=$ Ratchet strain at 200 cycles. 


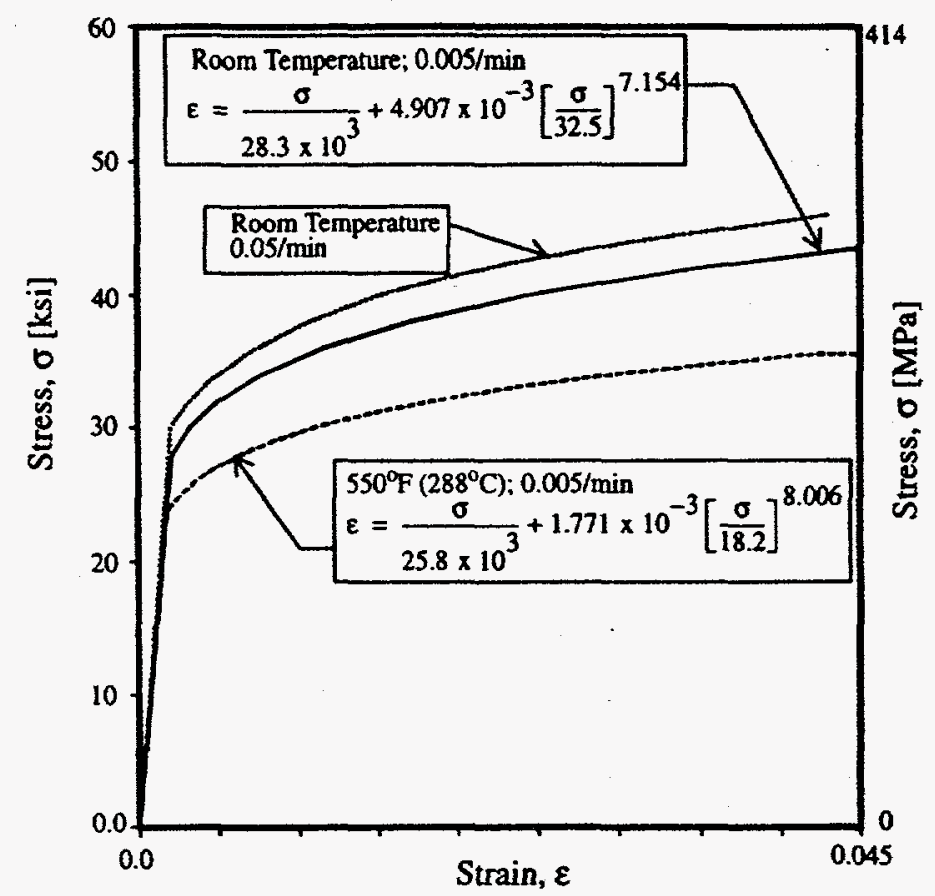

FIGURE 1. ROOM TEMPERATURE AND $550^{\circ} \mathrm{F}\left(288^{\circ} \mathrm{C}\right)$ MONOTONIC STRESS STRAIN CURVE

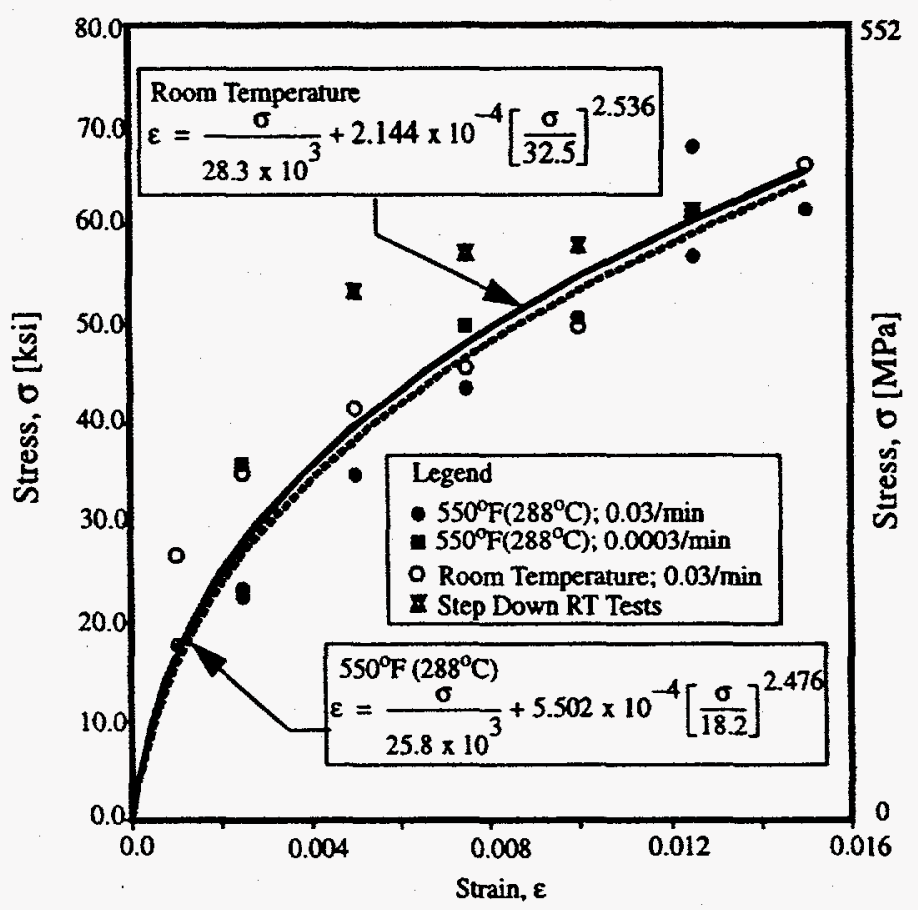

FIGURE 2. ROOM TEMPERATURE AND $550^{\circ} \mathrm{F}\left(288^{\circ} \mathrm{C}\right)$ CYCLIC STRESS STRAIN CURVES 

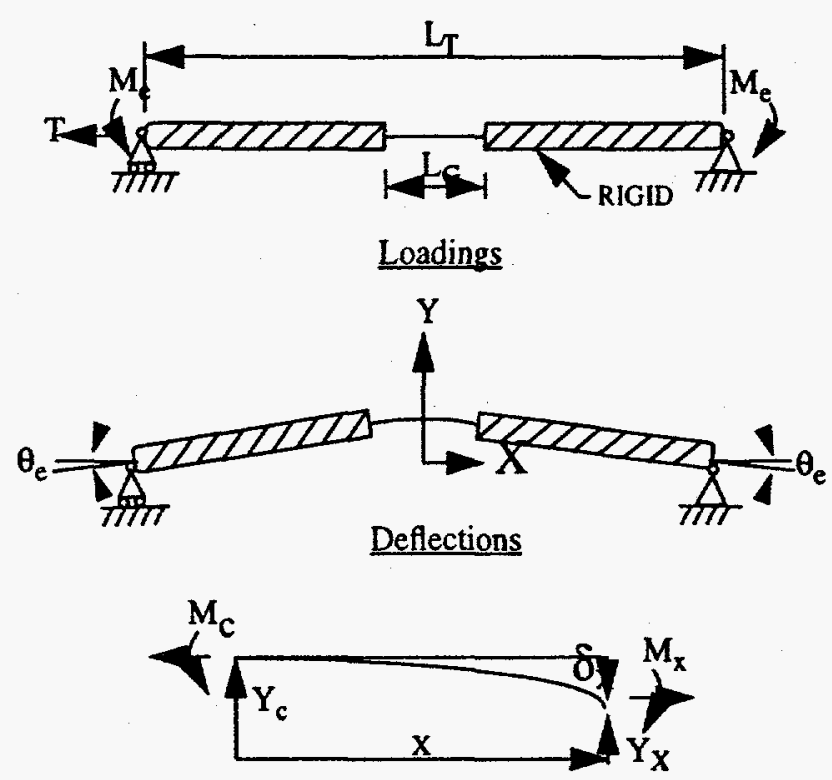

Free Body Forces

FIGURE 3. TENSION BENDING TEST CONCEPT
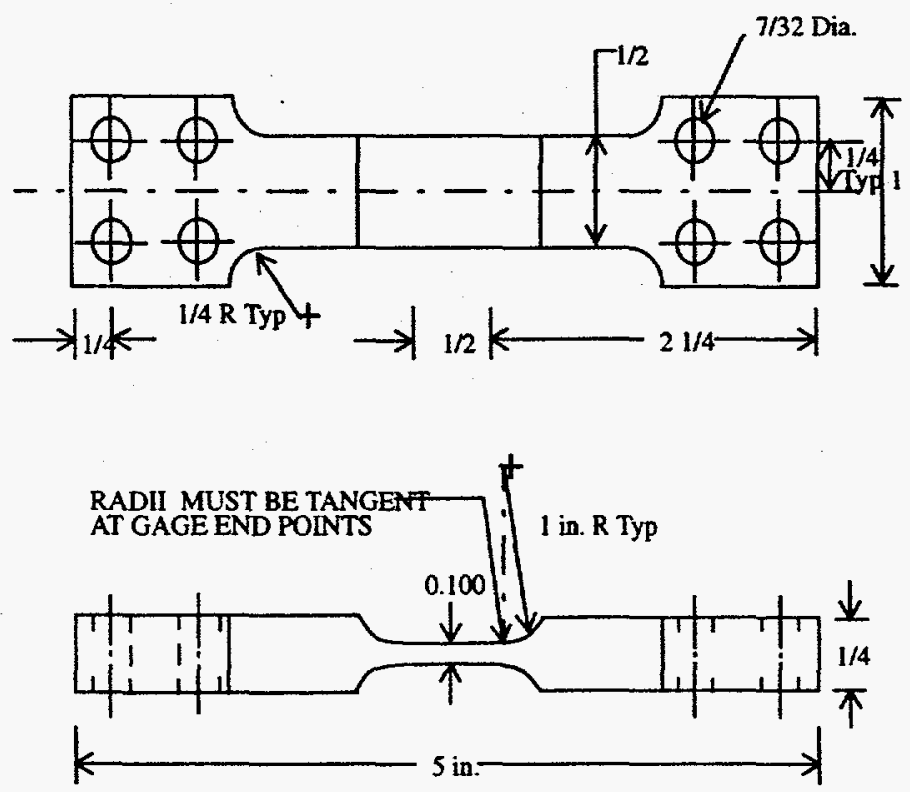

FIGURE 4. TENSION BENDING TEST SPECIMEN 


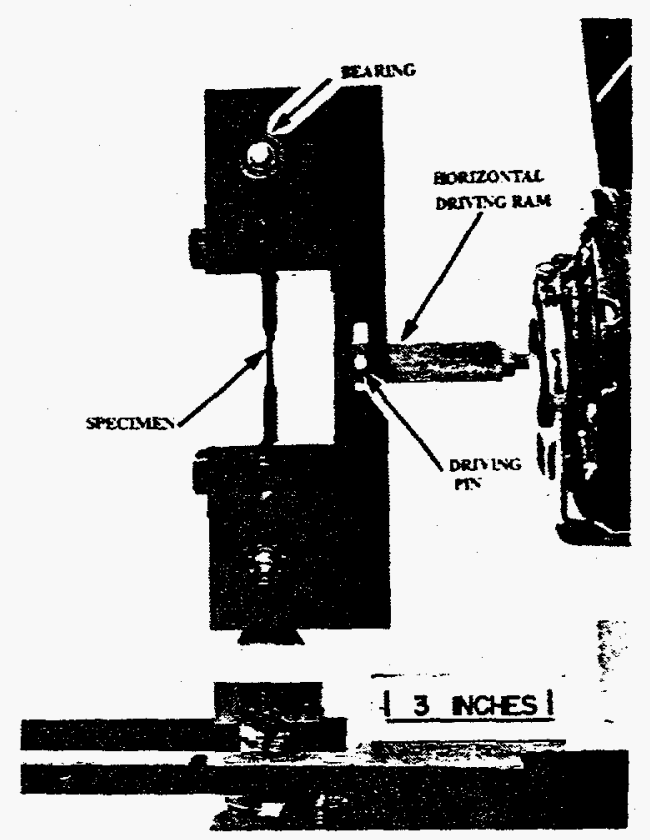

FIGURE 5. TENSION-BENDING TEST; SPECIMEN HOLDING JIG

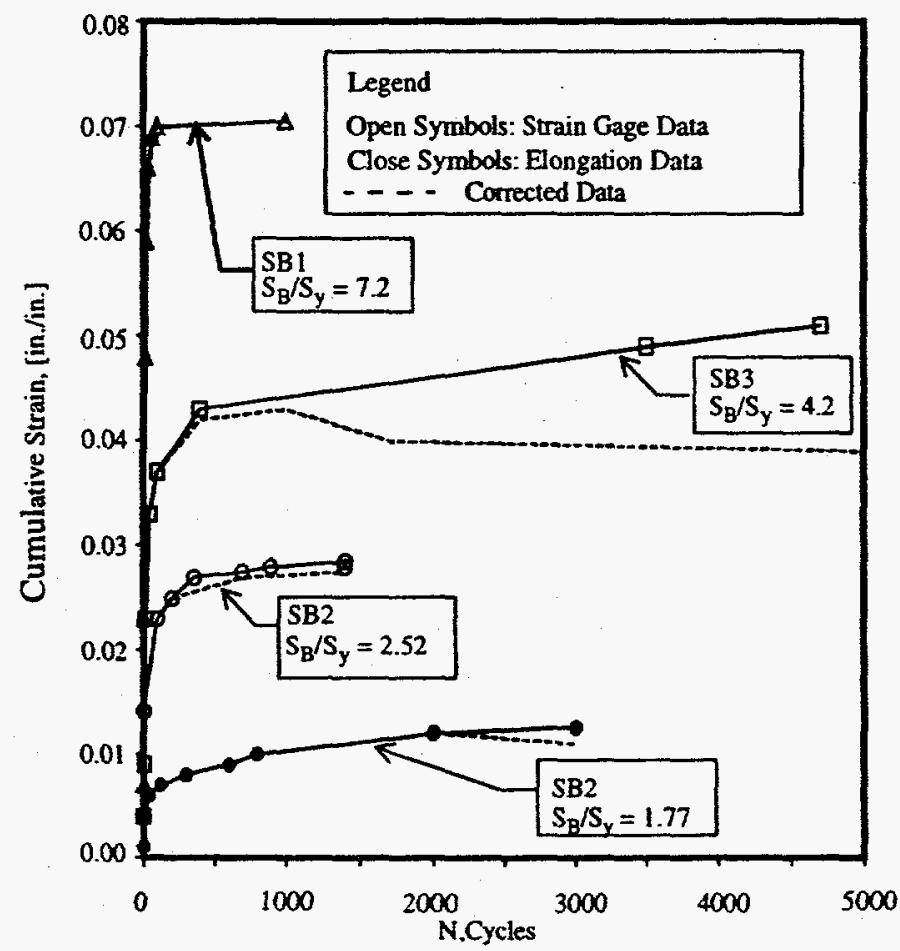

FIGURE 6. CUMULATIVE STRAIN VS. CYCLES; ROOM TEMPERATURE; $S_{w} / S_{y}=2 / 3$ 


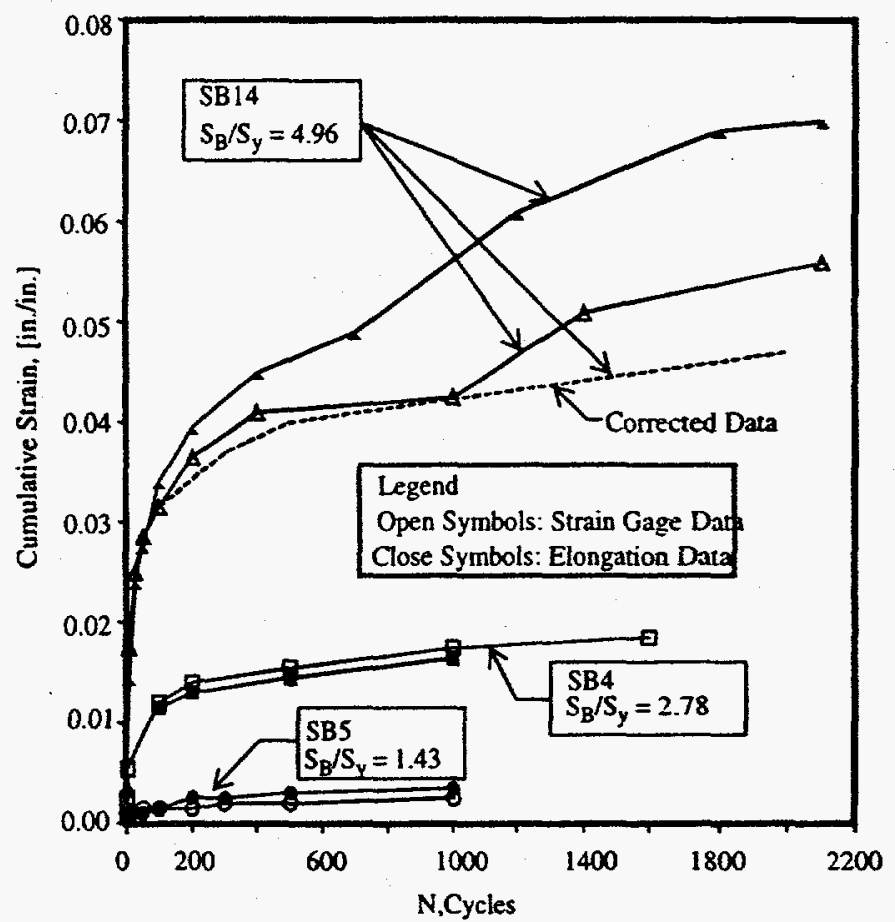

FIGURE 7. CUMULATIVE STRAIN VS. CYCLES; ROOM TEMPERATURE; $S_{\mathbf{w}} / S_{\mathbf{y}}=1 / 2$

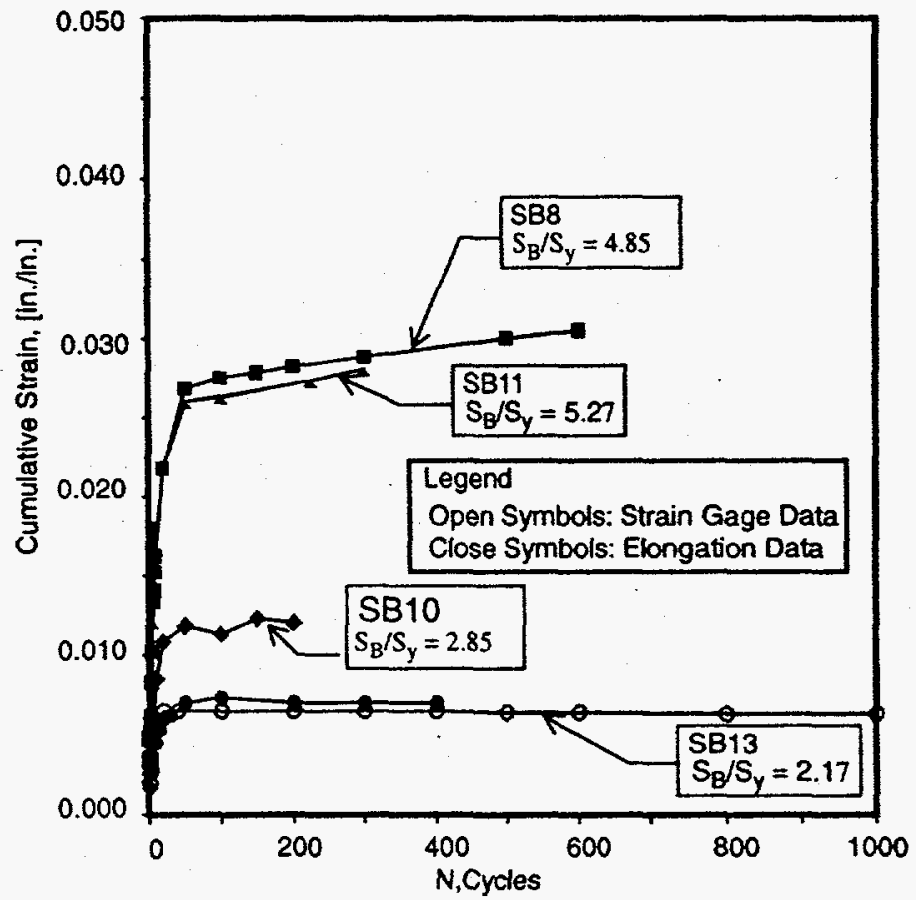

FIGURE 8. CUMULATIVE STRAIN VS. CYCLICS; $550^{\circ} \mathrm{F}\left(288^{\circ} \mathrm{C}\right) ; S_{\mathbb{M}} / S_{\mathrm{y}}=2 / 3$ 


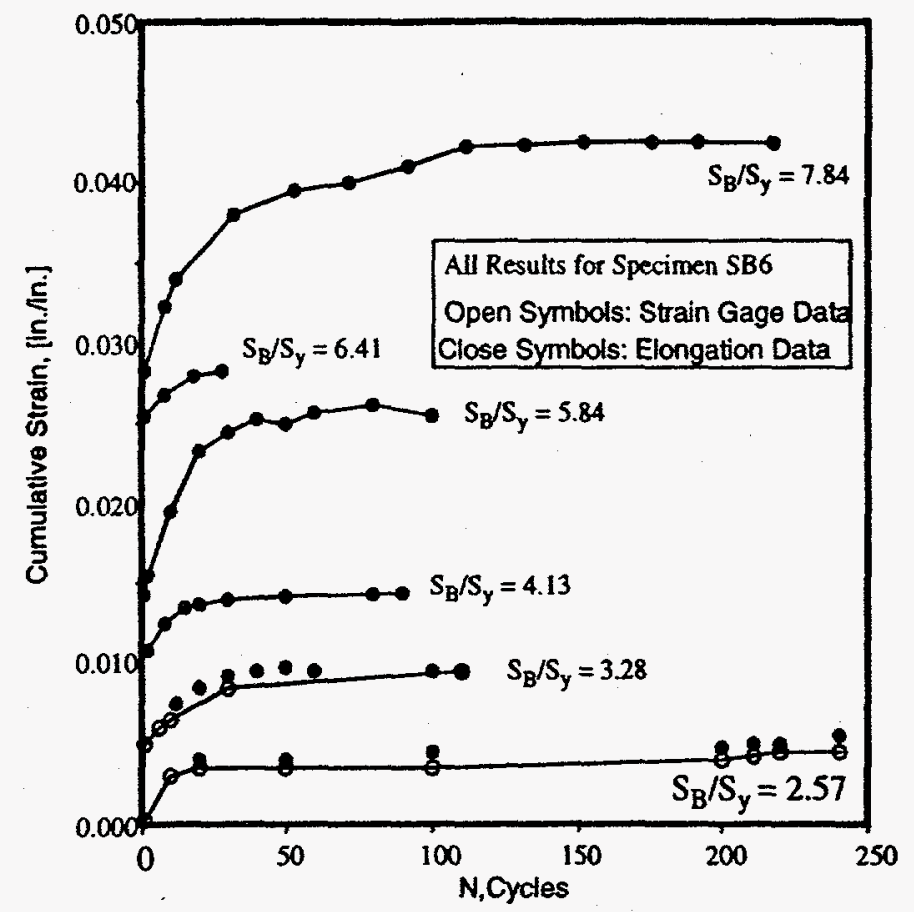

FIGURE 9. CUMULATIVE STRAIN VS. CYCLES; $550^{\circ} \mathrm{F}\left(288^{\circ} \mathrm{C}\right) ; S_{w} / S_{y}=1 / 2$

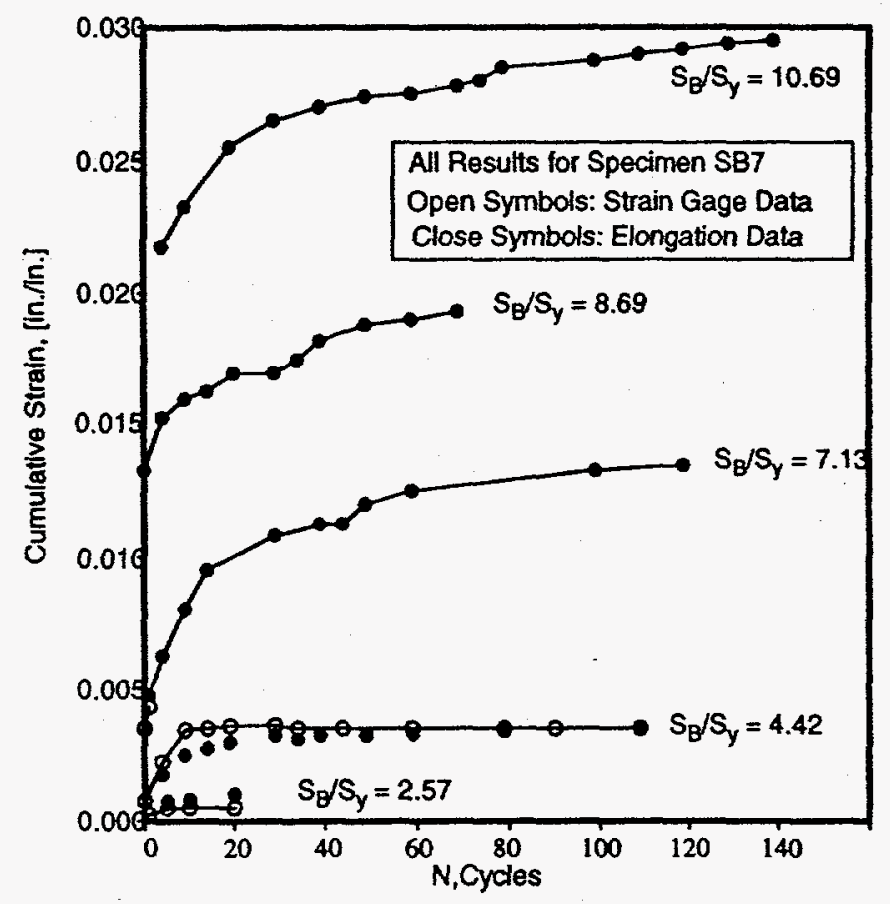

FIGURE 10. CUMULATIVE STRAIN VS. CYCLES; $550^{\circ} \mathrm{F}\left(288^{\circ} \mathrm{C}\right) ; S_{\mathrm{w}} / \mathrm{S}_{\mathrm{y}}=1 / 3$ 


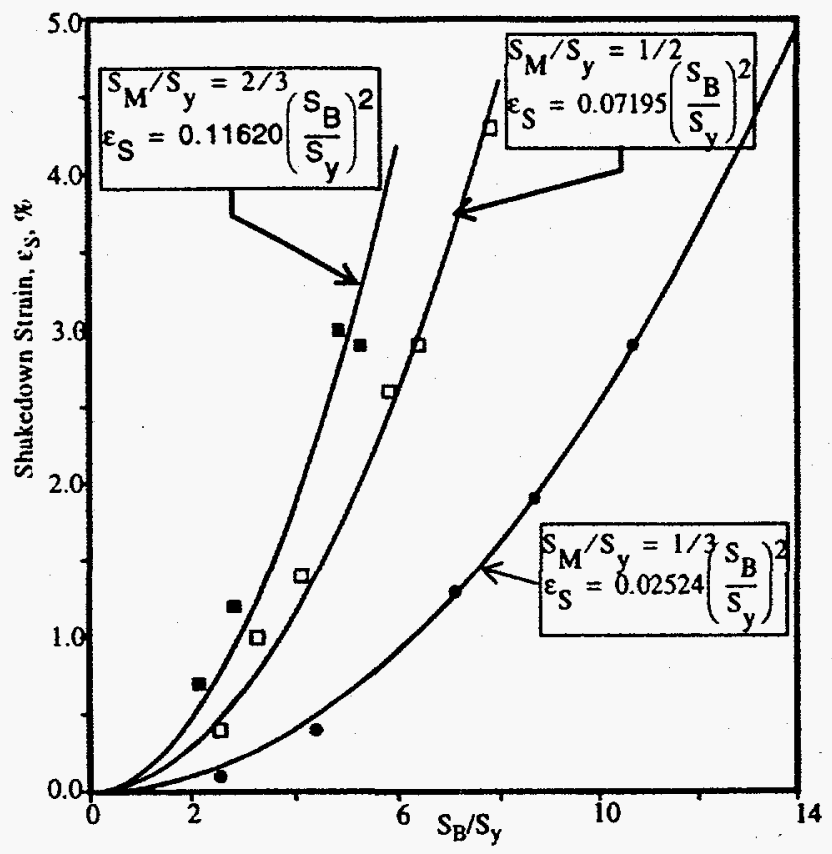

FIGURE 11. SHAKEDOWN STRAIN VS. BENDING STRESS; $550^{\circ} \mathrm{F}\left(288^{\circ} \mathrm{C}\right)$

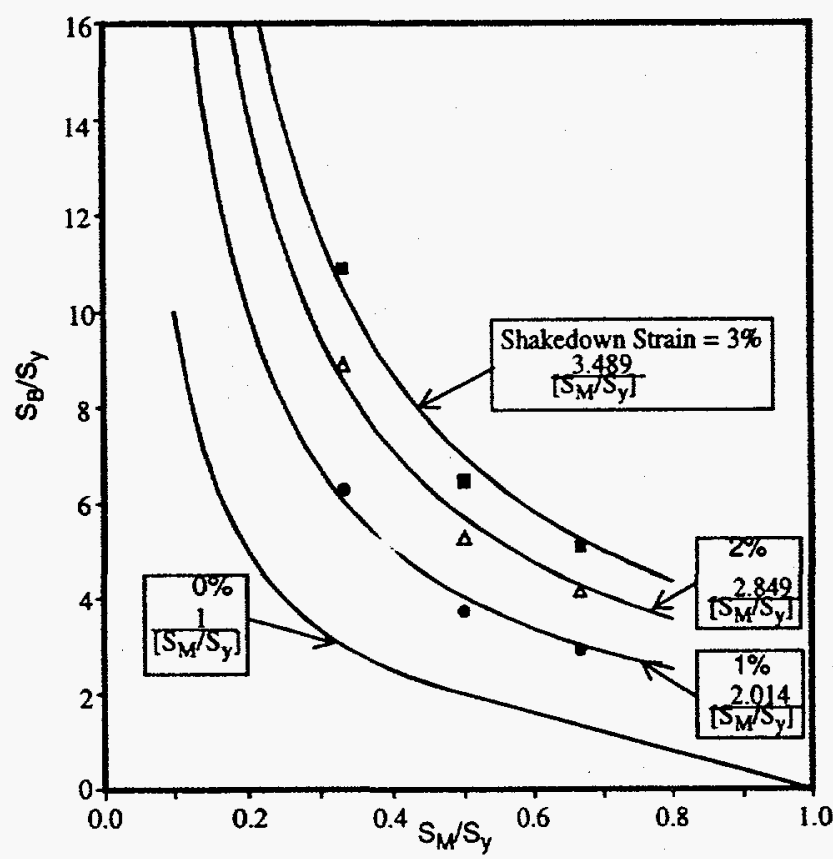

FIGURE 12. SHAKEDOWN DIAGRAM 